\title{
The Attitude of University Students to Participating in Sports for All in Saudi Arabia
}

\author{
Hebah H. AL Ohali \\ The Center for Promising Research in \\ Social Research and Women's Studies, \\ Princess Nourah bint Abdulrahman University, \\ Saudi Arabia
}

DOI: https://doi.org/10.36941/jesr-2020-012o

\section{Abstract}

The present study aims to investigate the attitude, obstacles, and suggestions for female students to participate in sports for all in Saudi Arabia. It adopted the social survey approach and applied the questionnaire and scale of attitude to a randomly selected sample of (375) students at King Saud University. The study concluded that the total score of the attitude was high. The cognitive, behavioral, and emotional aspects were ranked first, second, and third, respectively. The free time constraints, temperature, and weather fluctuations are the most significant obstacles, while increasing women's clubs and decreasing subscription fees are the most important constituents. The study recommends providing various and free sports activities, courses, and symposia to disseminate the culture of sports for all among university students.

Keywords: Attitude, Exercise, Sports for all, Saudi society, University student

\section{Introduction}

Sports for all are a contemporary social phenomenon for the recreation of all age groups worldwide. It maintains better fitness and health. Moreover, it is an educational and social necessity to resolve many contemporary problems, especially in the advanced countries, including spending free time, poor health, and tension at the time of technological advancement (Abdelsalam and Amer, 2016).

The World Health Organization (WHO) (2010) reports that $45 \%$ of adult diseases result from lack of movement and physical inactivity. Thus, regular physical activity decreases many diseases, e.g., stroke, diabetics, hypertension, colon cancer, and depression. Moreover, the frequency, intensity, period, and type of physical activity correlate with the required health benefits (WHO, 2010). In Saudi Arabia, (30\%) males and (28\%) females are obese due to the unbalanced diet and weak of sports practice (Ministry of Health, 2016).

Therefore, the General Sports Authority has expanded sports practice, participation in sports for all, and women participation in sports in Saudi Arabia. The Saudi Vision 2030 has stressed promoting woman health and sport activity because sports empowerment of the woman is health, psychological, social, and economic investment in a society that takes planned steps to development. In 2010, the General Authority for Statistics (2010) reported that (89\%) of the surveyed population stressed the importance of sports for the woman who does not practice sports because of the dominant social traditions. 
The present study is significant because it highlights the attitudes of female university students to sports for all according to the (cognitive, emotional, and behavioral) aspects of the scale, which in turn promotes the planning of sports activities at the university to fit the attitudes and interests of students. Its results will motivate taking some actions to develop positive attitudes and address and modify the negative ones. To the author's knowledge, it is the first study to address the attitudes towards sports for all among the female students at King Saud University.

\section{Statement of the Problem}

The present study investigates the attitudes of female students at King Saud University towards practicing sports for all in Saudi society. It raises the major question "what are the attitudes of university students towards practicing sports for all in the Saudi society?" that is subdivided into the following minor ones:

1. What is the attitude of university students towards participating in sports for all according to the (cognitive, emotional, and behavioral) aspects of the scale?

2. What are the obstacles to the participation of university students in sports for all in Saudi society?

3. What are the suggestions to activate the participation of university students in sports for all in Saudi society?

\section{Theoretical Framework and Literature Review}

The author adopts the descriptive approach because sports for all are a contemporary social phenomenon interested in recreation, health, physical condition, and lifestyle of the society members according to their attitudes, motifs, and readiness to participate in the social initiatives regardless of the age, gender, or educational and sociocultural level to achieve a better life. Universities play a considerable role in developing student attitudes towards participation in the physical activities for all on or off-campus to promote social cohesion and national belonging.

The author employs the (social) action theory because Saudi society has experienced rapid changes in the value system and a gap between the new systems and legislation and reality socially and culturally. Because of their traditional thinking and actions, some people do not think that sports for all are not important, especially for the woman. On the contrary, some people stress the importance of sports for health.

The attitude comprises three aspects, namely the cognitive, emotional, and behavioral. While the cognitive aspect covers the beliefs, ideas, perceptions, and information about a certain issue, even if they do not rely on objective facts or notes (Aljebaly, 2003, p.237). The emotional aspect refers to the various feelings and emotions towards an issue that suggest a positive or negative attitude (Alzahra, 2006). According to Aljebaly (2003), the behavioral aspect is the individual's readiness to take actions and responses that match his attitude towards a certain issue in social action. The author argues that the three aspects vary in terms of severity, independence, and effect. For example, a person may have adequate information and facts about an issue (the cognitive aspect) but does not desire or tend to interact emotionally (the emotional aspect) to take a behavioral response or action (the behavioral aspect).

Kenza (2014) reports some functions of the attitude. While the adjustment function helps build adjustment relations with individuals and groups inside and outside the community, the selfactualization function helps the person express himself and define social identity and status. The organizational function represents an organized and relatively stable form of behavior towards social issues and situations.

Many studies addressed the importance of the attitude towards the practice of sports. For example, Abdelsalam and Amer (2016) investigated women's attitudes towards sports for all. They utilized the scale of attitudes to collect data and concluded statistically significant differences in the 
domains of the scales in favor of the practitioner of sports activities.

Alatrash (2016) explored the attitudes towards sports activity using the scale of attitudes. The study reported statistically significant differences between the pre-test and post-test of student attitudes after studying the Physical Fitness Course in favor of the post-test. Alsayed and Abdelsalam (2014) explored the attitudes of students towards sports for all using the scale of attitudes that comprised four domains (i.e. the attitude towards the concept of sports for all, the importance of sports for all, the attitude towards community support of sports, and the attitude towards international cooperation in sports for all). The results showed a positive attitude in all domains. Moreover, there were statistically significant differences in all domains favoring the higher class. Mirsafian, Dóczi, and Mohamadinejad (2014) identified the attitudes of Iranian university students to sports using in-depth interviews and Kenyon's attitude scale toward physical activities. The results showed that most of the participants' attitudes were negative. Additionally, only $18 \%$ of the participants exercise twice or more weekly. Marques, Martins, Santos, Sarmento, and Carreiro da Costa (2014) investigated the factors related to sports games in Portugal using a questionnaire and a cross-sectional survey of $(2,617)$ students. The results revealed various factors affecting the males' sport participation, such as regular exercise and attitude towards sports, while the females' participation was related to age, regular exercise, attitude towards sports, and fame.

Aljafra (2013) examined the attitudes of the secondary school students in Ma'an Governorate, Jordan to sports activity in the Physical Education Course using a questionnaire of the (health, social, teacher personality, and mental) domains. The results showed high positive attitudes among the participants to sport exercise. While the health domain was ranked first, the teacher personality was ranked last. Aljifri (2013) explored the attitudes of the students of King Abdulaziz University to physical activity using a questionnaire covering its effect of the (health, social, psychological, and scientific) domains. The findings illustrated that the attitudes of the participants were positive. While the health domain was ranked first, the social domain was ranked last.

Zayed, Al-Jebali, and Al-Shoaili (2004) investigated the attitudes of the students of Sultan Qaboos University to sports activity using Kenyon's attitude scale that comprises six domains, i.e. tension and risk, competition and excellence, aesthetic experience, health and fitness, social experience, and recreation and tension reduction. The results highlighted the positive attitudes of the participants towards sports activity. Moreover, Zeyab (2004) developed a scale to identify the attitudes of Kuwait University students to sports for all and showed positive attitudes among the participants. Barsom (2003) utilized the questionnaire and interviews to examine the reasons for the reluctance of students at Helwan University hostels to participate in the sports activity. The participants were reluctant to participate because of the low sport's awareness, feeling tired after the academic day, spending a long time at the scientific colleges, lack of equipment, and undiversified sports activities.

The present study explores sports as a social phenomenon in terms of the functional form, social function, and reciprocal relations with the various social systems. A functional relationship was reported between sports and society that differs in severity and attitude according to the social culture and historical background. Therefore, Coakley (2014) reviewed the social values of sports for all, i.e. cooperation, sportsmanship, self-control, social development, fitness, enjoyment, good citizenship, accepting others, etc. Mousavi (2012) concluded a higher significant impact of group sports on social adjustment. Additionally, sports implement positive social values, such as cooperation, enjoyment, and accepting others. Alkabey (2013) suggested a strong relationship between the social environment and sports because of facilitating the integration in various sports activities and protecting from crime and deviation.

Sport is a key part of the educational system that aims to prepare the citizen physically, psychologically, and mentally. It has an educational value itself (Zober, 2014). Thus, many studies that explored the effect of sports activities on achievement showed positive effects of the regular exercise on performance and achievement (Alshahrey, 2007). Grissom (2005) also showed a positive correlation between fitness and achievement.

Sports is not a social and entertainment activity only, but it is an economic activity causing profit 
and loss. Perks (2019) examined the effect of the socio-economic conditions on sport participation among $(4,858)$ children and adolescents. The results showed that the socio-economic condition affects sport participation from childhood to adolescence, but it is relatively small if compared to other factors.

Alkabey (2013) reported some economic and commercial reasons for the investment in sports for women, especially the international success of women in competitions, the strong demand for women's sports, and taking sports as a social information tool to access decision-makers. The author argues that Saudi Arabia is interested in sports investment. Thus, the General Sports Authority facilitated the issuance of licenses and began the electronic services of licensing sports center gymnasiums to promote exercise and sports investment. Alsaleh (2016) reported that investment in women's sports in Saudi Arabia has opened new horizons, created about 250 job opportunities for the women in the sports field, and aspired to make sports a daily necessity.

The Saudi Vision 2030 (20116) has paid considerable interest in sports. For instance, Saudi Arabia encourages the different types of sports locally and internationally by establishing many sports facilities in collaboration with the private sector. Thus, everyone can exercise in an environment that tracks the latest updates and international sports events can be held. Launching the National Program Daem (Support) has improved the quality of sports and cultural activities and provided financial support by establishing a national network that covers all clubs, transfers the best expertise and international practices, and raises awareness of its importance.

Sports are highly important for women. In terms of health, the woman should practice sports to keep healthy, reduce laziness, and keep diseases away (Alwalaney, 2015). Moreover, sports relieve menstrual pain and help lose weight after pregnancy. Psychologically, Mahmoud (2012) reports that sports play a key role in the daily life of the woman by reducing stress and achieving self-reliance. Alhabdan (2017) argues that sport reduces negative shyness and isolation and enhances self-confidence, decision-making, and behavior control among females. Additionally, it promotes psychological resilience and reduces psychological disorders.

Socially, sport affects the woman by promoting positive social values, e.g., cooperation, competition, constructive social interaction, and time management (Alkabey, 2013). Aesthetically, sport strengthens the muscles to achieve fitness. There is a negative correlation between sport and aging, especially for women because sport builds fitness, delays wrinkles, and helps weight control (Alhamed, 2015). According to Alwalaney (2015), the quality of life is largely related to recreation that causes adjustment, happiness, and satisfaction. Hall (2005) argues that sports are a major contributor to the feelings of health, wellness, and high quality of life.

Many studies investigated the importance of sports for women. For example, Alhabdan (2017) examined the psychological and health impacts of the practice of sports on Saudi girls. The results showed that $(80 \%)$ of the participants believed that sports have positive psychological impacts by reducing negative shyness, depression, isolation, and frustration. Most of the participants agreed that sports enhance self-confidence, self-esteem, and decision-making. Moreover, they reported that sports improve health and fitness.

Alkabey (2013) explored the sociocultural determinants affecting the practice of sports among women in Saudi society. The study highlighted the reality of women's sports in Saudi Arabia and highlighted the relation between economics and women's sports. The results showed that some traditions contradict women's practice of sports. However, $(73 \%)$ of the participants motivated women's practice of sports, which necessitates more official and social support.

Women's sports have increased in Saudi Arabia. Since 2016, Saudi Arabia has improved this issue by facilitating the issuance of women's gymnasiums and including courses of physical education in the public schools for girls. Moreover, the Ministry of Sports signed agreements with (14) Saudi universities to launch training programs that qualify female fitness trainers and to activate the women's sports programs and events (Alamodey, 2012). 


\section{Methodology}

\subsection{Method}

The study adopted the analytical descriptive approach to describe the attitude of the participants towards joining programs of sports for all. It also used the social survey approach because it is the most appropriate to the nature of the study to get information and make conclusions about the attitudes of the students to sports for all.

\subsection{Population}

The population of the study covered the regular female undergraduates in the second semester of 2018/2019. The documents of the Department of Admission and Registration showed that the population comprised $(14,183)$ students.

Table (1): Number of female students at King Saud University in the second semester of 2018/2019

\begin{tabular}{|c|l|c|}
\hline Colleges & College & No. of students \\
\hline \multirow{5}{*}{ Humanities } & Arts & $\mathbf{2 , 4 8 4}$ \\
\cline { 2 - 3 } & Education & $\mathbf{1 , 8 5 8}$ \\
\cline { 2 - 3 } & Law and Political Sciences & $\mathbf{1 , 6 0 4}$ \\
\cline { 2 - 3 } & Languages and Translation & $\mathbf{1 , 0 9 1}$ \\
\cline { 2 - 3 } & Sport Sciences and Physical Activity & 59 \\
\hline \multirow{5}{*}{ Science } & Business Administration & $\mathbf{2 , 1 4 0}$ \\
\cline { 2 - 3 } & Computer and Information Sciences & $\mathbf{1 , 2 4 6}$ \\
\cline { 2 - 3 } & Science & $\mathbf{1 , 0 6 7}$ \\
\hline \multirow{5}{*}{ Health } & Nursing & $\mathbf{2 8 0}$ \\
\cline { 2 - 3 } & Pharmacy & 436 \\
\cline { 2 - 3 } & Medicine & 668 \\
\cline { 2 - 3 } & Dentistry & $\mathbf{2 9 4}$ \\
\cline { 2 - 3 } & Applied Medical Sciences & 956 \\
\hline Total & & $\mathbf{1 4 , 1 8 3}$ \\
\hline
\end{tabular}

\subsection{Sampling}

The author distributed (390) questionnaires; (130) at all (health, science, and humanities) colleges. Later, (15) incomplete questionnaires were excluded. Thus, the sample covered (375) female students.

\subsection{Tools}

\subsubsection{The scale of attitude towards sports for all}

The scale aims to explore the attitudes of the female students at King Saud University towards participation in sports for all. It aims to highlight the obstacles and suggestions for activating their participation. Therefore, the author reviewed literature and some relevant scales, such as the scales of Bogardos, Thurston, Likert, Guttman, and Osgood. The instructions of the scale were formulated to include personal data (e.g., age, social status, residence, sport, weekly rate of exercise, type of physical activity, place of exercise, parents' practice of physical activity, and parents' exercises). They also covered economic variables (monthly income of the family) and the academic variables (major and academic level). The participants were informed that there are no right and wrong answers and that all items should be answered.

The scale comprised a set of domains affecting the attitude of university students towards 
participation in the programs of sports for all. While the cognitive aspect shows the student's awareness of sports for all, the emotional one measures the emotional attitude of the student to the activities of sports for all. The behavioral aspect measures the behavioral readiness of the student to practice the activities of sports for all in or off-campus. Moreover, the author adopted a five-point Likert scale to show agreement: (5) strongly agree, (4) agree, (3) undecided, (2) disagree, and (1) strongly disagree.

Table (2): Domains and items of the scale

\begin{tabular}{|c|c|c|c|}
\hline Domain & Sub-domain & Items & Total \\
\hline \multirow{3}{*}{ The attitude of the student to participate in the programs of sports for all } & Cognitive & 9 & \multirow{3}{*}{27 items } \\
\hline & Emotional & 9 & \\
\hline & Behavioral & 9 & \\
\hline \multicolumn{3}{|l|}{ Obstacles to participation in the programs of sports for all } & 13 items \\
\hline \multicolumn{3}{|l|}{ Suggestions to activate participation in the programs of sports for all } & 11 items \\
\hline \multicolumn{3}{|l|}{ Total } & 51 items \\
\hline
\end{tabular}

The reviewer's validity: The preliminary draft of the scale was presented to some faculty members at King Saud University specialized in sociology, social work, and sciences of sports and physical activity. They gave opinions on the clarity of instructions, the importance of the key factors, relation of items to the domain, item appropriateness, linguistic and academic formedness. They made some notes and suggestions. In light of their modifications, the final form consisted of (3) domains and (51) items. Then, the internal validity of the items was estimated by calculating the correlation between the items and the total score of the scale.

Table (3): Correlation coefficients between the items and the total score of the scale

\begin{tabular}{|c|c|c|c|c|c|}
\hline \multicolumn{6}{|l|}{ Domain I } \\
\hline Sub-domain & Item & Correlation & ent & Item & Correlation coefficient \\
\hline \multirow{5}{*}{ Cognitive } & 1 & \multicolumn{2}{|c|}{$* *_{0} .680$} & 6 & $* * 0.770$ \\
\hline & 2 & \multicolumn{2}{|c|}{$* * 0.702$} & 7 & $* * 0.746$ \\
\hline & 3 & \multicolumn{2}{|c|}{$* * 0.727$} & 8 & $* * 0.784$ \\
\hline & 4 & \multicolumn{2}{|c|}{$* * 0.814$} & 9 & $* * 0.627$ \\
\hline & 5 & \multicolumn{2}{|c|}{$* * 0.623$} & - & - \\
\hline \multirow{5}{*}{ Emotional } & 10 & \multicolumn{2}{|c|}{$* * 0.584$} & 15 & $* * 0.798$ \\
\hline & 11 & \multicolumn{2}{|c|}{$* * 0.591$} & 16 & $* * 0.607$ \\
\hline & 12 & \multicolumn{2}{|c|}{$* * 0.611$} & 17 & $* * 0.699$ \\
\hline & 13 & \multicolumn{2}{|c|}{$* * 0.642$} & 18 & $* * 0.686$ \\
\hline & 14 & \multicolumn{2}{|c|}{$* * 0.700$} & - & - \\
\hline \multirow{5}{*}{ Behavioral } & 19 & \multicolumn{2}{|c|}{$* * 0.513$} & 24 & $* * 0.838$ \\
\hline & 20 & \multicolumn{2}{|c|}{$* * 0.646$} & 25 & $* * 0.654$ \\
\hline & 21 & \multicolumn{2}{|c|}{$* * 0.761$} & 26 & $* *_{0.711}$ \\
\hline & 22 & \multicolumn{2}{|c|}{$* * 0.618$} & 27 & $* * 0.635$ \\
\hline & 23 & \multicolumn{2}{|c|}{$* * 0.606$} & - & - \\
\hline Domain II & & & & & \\
\hline Item & Corr & tion coefficient & Item & & Correlation coefficient \\
\hline 1 & & $* * 0.722$ & 8 & & $* * 0.542$ \\
\hline 2 & & $* * 0.559$ & 9 & & $* * 0.796$ \\
\hline 3 & & $* * 0.649$ & 10 & & $* * 0.611$ \\
\hline 4 & & $* * 0.632$ & 11 & & $* * 0.672$ \\
\hline 5 & & $* * 0.578$ & 12 & & $* * 0.590$ \\
\hline 6 & & $* *_{0} .634$ & 13 & & $* * 0.653$ \\
\hline 7 & & $* * 0.685$ & - & & - \\
\hline
\end{tabular}




\begin{tabular}{|c|c|c|c|}
\hline Domain III & \multicolumn{3}{|c|}{} \\
\hline Item & Correlation coefficient & Item & Correlation coefficient \\
\hline 1 & $* *_{0} .693$ & 7 & $* *_{0} .763$ \\
\hline 2 & $* *_{0} 0.548$ & 8 & $* *_{0} .676$ \\
\hline 3 & $* *_{0} .582$ & 9 & $* *_{0} .676$ \\
\hline 4 & $* *_{0} 0.738$ & 10 & $* *_{0} .623$ \\
\hline 5 & $* *_{0} 0.569$ & 11 & $* *_{0} .587$ \\
\hline 6 & $* *_{0} .813$ & - & - \\
\hline
\end{tabular}

The correlation coefficients are in the closed interval [0.542- 0.838 ]. Thus, all correlation coefficients are statistically significant at the level of (o.o1), suggesting their validity.

The reliability of the scale was defined using Cronbach's alpha. It equaled o.8o to suggest that the scale is highly reliable.

Table (4): Cronbach's alpha coefficients of the scale

\begin{tabular}{|l|l|c|c|}
\hline Domains & Items & Reliability \\
\hline \multirow{3}{*}{ The attitude of the student to participate in the programs of sports for all } & Cognitive & 9 & 0.8652 \\
\cline { 2 - 4 } & Emotional & 9 & 0.7941 \\
\cline { 2 - 4 } & Behavioral & 9 & 0.7756 \\
\hline Obstacles to participation in the programs of sports for all & 13 & 0.7271 \\
\hline Suggestions to activate participation in the programs of sports for all & 11 & 0.8162 \\
\hline Total reliability & 51 & 0.7956 \\
\hline
\end{tabular}

Therefore, the final form of the scale is ready for application.

\section{Results and Discussion}

To answer the first question, the arithmetic mean, standard deviation, percentage, and rank of the participants' responses to the attitudes of King Saud University students to participate in sports for all were calculated.

Table (5): The participants' responses to the attitudes of King Saud University students to participate in sports for all

\begin{tabular}{|c|l|c|c|c|c|}
\hline No. & Domain & Arithmetic mean & Standard deviation & Percentage & Rank \\
\hline 1 & Cognitive & 4.49 & 0.490 & $89.8 \%$ & 1 \\
\hline 2 & Emotional & 4.14 & 0.483 & $82.8 \%$ & 3 \\
\hline 3 & Behavioral & 4.21 & 0.522 & $84.2 \%$ & 2 \\
\hline \multicolumn{2}{|c|}{ Total } & 4.28 & 0.416 & $85.6 \%$ & - \\
\hline
\end{tabular}

Table (5) shows that the three domains were highly positive. The cognitive, behavioral, and emotional domains were ranked first, second, and third, respectively. This finding agrees with the findings of Aljafra (2013) that attitudes of the secondary stage students are high towards women's practice of sports and Alkabey (2013) that (73\%) of the participants encourage women's practice of sports. It differs from the findings of Mirsafian et al. (2014) that most of the participants have negative attitudes to sports and only $(18 \%)$ of them exercise twice or more weekly.

To identify the cognitive aspect of the student attitude towards participation in sports for all, the frequency, percentage, arithmetic mean, standard deviation, and rank of the responses were calculated. 
Table (6): Responses of the participants to the cognitive aspect of the attitudes of university students to participate in sports for all

\begin{tabular}{|c|c|c|c|c|c|c|c|c|c|c|}
\hline \multirow[b]{2}{*}{ No. } & \multirow[b]{2}{*}{ Item } & \multirow{2}{*}{\begin{tabular}{|l|} 
Frequency \\
Percentage
\end{tabular}} & \multicolumn{5}{|c|}{ Agreement } & \multirow{2}{*}{ 总 } & \multirow{2}{*}{ 吾 } & \multirow{2}{*}{$\frac{2}{\pi}$} \\
\hline & & & $\begin{array}{l}\text { Strongly } \\
\text { agree }\end{array}$ & Agree & Undecided & Disagree & $\begin{array}{l}\text { Strongly } \\
\text { disagree }\end{array}$ & & & \\
\hline \multirow{2}{*}{8} & \multirow{2}{*}{ Sports promote mental health. } & $\mathrm{F}$ & 274 & 83 & 16 & 2 & - & \multirow{2}{*}{4.68} & \multirow{2}{*}{0.580} & \multirow{2}{*}{1} \\
\hline & & $\%$ & 73.1 & 22.1 & $4 \cdot 3$ & 0.5 & - & & & \\
\hline \multirow{2}{*}{7} & \multirow{2}{*}{ Sport is a means of enjoyment and recreation. } & $\mathrm{F}$ & 264 & 94 & 14 & 3 & - & \multirow{2}{*}{4.65} & \multirow{2}{*}{0.592} & \multirow{2}{*}{2} \\
\hline & & $\%$ & 70.4 & 25.1 & 3.7 & 0.8 & - & & & \\
\hline \multirow[b]{2}{*}{3} & \multirow{2}{*}{$\begin{array}{l}\text { Sports for all protect against the symptoms of some } \\
\text { modern behaviors (laziness, inactivity, and } \\
\text { excessive use of electronic devices). }\end{array}$} & $\mathrm{F}$ & 254 & 105 & 13 & 3 & - & \multirow[b]{2}{*}{4.63} & \multirow[b]{2}{*}{0.593} & \multirow[b]{2}{*}{3} \\
\hline & & $\%$ & $67 \cdot 7$ & 28 & $3 \cdot 5$ & 0.8 & - & & & \\
\hline \multirow{2}{*}{4} & \multirow{2}{*}{$\begin{array}{l}\text { The activities of sports for all help manage spare } \\
\text { time positively. }\end{array}$} & $\mathrm{F}$ & 237 & 120 & 16 & 1 & 1 & \multirow{2}{*}{4.58} & \multirow{2}{*}{0.615} & \multirow{2}{*}{4} \\
\hline & & $\%$ & 63.1 & 32 & $4 \cdot 3$ & 0.3 & 0.3 & & & \\
\hline \multirow{2}{*}{2} & \multirow{2}{*}{ Sports for all are the right of all. } & $\mathrm{F}$ & 216 & 124 & 33 & 1 & 1 & \multirow{2}{*}{$4 \cdot 47$} & \multirow{2}{*}{0.689} & \multirow{2}{*}{5} \\
\hline & & $\%$ & 57.5 & 33.1 & 8.8 & 0.3 & 0.3 & & & \\
\hline \multirow{2}{*}{6} & Sports for all cover all sports and games selected & $\mathrm{F}$ & 199 & 131 & 41 & 3 & 1 & & & 6 \\
\hline & based on attitudes and capabilities. & $\%$ & 53.1 & $34 \cdot 9$ & 10.9 & 0.8 & 0.3 & 4.40 & 0.735 & 0 \\
\hline & Sports for all promote positive values (cooperation, & $\mathrm{F}$ & 194 & 133 & 37 & 11 & - & & & \\
\hline 5 & positive competition, altruism, etc.). & $\%$ & 51.7 & 35.5 & 9.9 & 2.9 & - & 4.30 & 0.778 & 7 \\
\hline 9 & Sports for all accomplish an important goal of the & $\mathrm{F}$ & 216 & 87 & 59 & 10 & 3 & & 10802 & 8 \\
\hline 9 & Saudi Vision 2030 by building a vibrant society. & $\%$ & 57.6 & 23.2 & 15.7 & 2.7 & 0.8 & $4 \cdot 34$ & 0.09 & 0 \\
\hline 1 & Sports for all are concerned with the health of all & $\mathrm{F}$ & 185 & 136 & 42 & 8 & 4 & & & \\
\hline & society members. & $\%$ & $49 \cdot 3$ & 36.3 & 11.2 & 2.1 & 1.1 & 4.31 & 0.833 & 9 \\
\hline Tot & & & & & & & & 4.49 & 0.49 & \\
\hline
\end{tabular}

Table (6) shows that the participants strongly agreed on this domain. Item (8) was ranked first, suggesting that the students understand that sport makes them feel relaxed and promotes mental health. This finding matches Alhabdan (2017) that showed that $(80 \%)$ of the participants perceive positive psychological impacts of exercise. It also agrees with Aljifri (2013) that illustrated that the health domain was ranked first. On the contrary, item (1) was ranked first, suggesting that the students believe that sport keeps the physical activity and vitality and protects from diseases. This finding coincides with Alhabdan (2017) that most of the participants agreed that sports make their health better and improve fitness.

To identify the emotional aspect of the student attitude towards participation in sports for all, the frequency, percentage, arithmetic mean, standard deviation, and rank of the responses were calculated.

Table (7): Responses of the participants to the emotional aspect of the attitudes of university students to participate in sports for all

\begin{tabular}{|c|c|c|c|c|c|c|c|c|c|c|}
\hline \multirow[b]{2}{*}{ No } & \multirow[b]{2}{*}{ Item } & \multirow{2}{*}{\begin{tabular}{|l|} 
Frequency \\
Percentage
\end{tabular}} & \multicolumn{5}{|c|}{ Agreement } & \multirow{2}{*}{ 总 } & \multirow{2}{*}{ 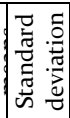 } & \multirow{2}{*}{ 䒕 } \\
\hline & & & $\begin{array}{c}\text { Strongly } \\
\text { agree }\end{array}$ & Agree & Undecided & Disagree & $\begin{array}{l}\text { Strongly } \\
\text { disagree }\end{array}$ & & & \\
\hline \multirow{2}{*}{16} & \multirow{2}{*}{ Sport exercise makes me feel happy and relaxed. } & $\mathrm{F}$ & 238 & 118 & 16 & 3 & - & \multirow{2}{*}{$4 \cdot 58$} & \multirow{2}{*}{0.615} & \multirow{2}{*}{1} \\
\hline & & $\%$ & 63.4 & 31.5 & 4.3 & 0.8 & - & & & \\
\hline \multirow{2}{*}{15} & \multirow{2}{*}{ Sport exercise enhances self-confidence. } & $\mathrm{F}$ & 242 & 104 & 23 & 6 & - & \multirow[b]{2}{*}{$4 \cdot 55$} & \multirow{2}{*}{0.684} & \multirow{2}{*}{2} \\
\hline & & $\%$ & 64.6 & 27.7 & 6.1 & 1.6 & - & & & \\
\hline \multirow{2}{*}{11} & \multirow{2}{*}{ Sport exercise decreases life stress. } & $\mathrm{F}$ & 213 & 137 & 15 & 10 & - & \multirow[b]{2}{*}{4.47} & \multirow{2}{*}{0.700} & \multirow[b]{2}{*}{3} \\
\hline & & $\%$ & 56.8 & 36.5 & 4 & 2.7 & - & & & \\
\hline \multirow{2}{*}{12} & \multirow{2}{*}{$\begin{array}{l}\text { Group sports motivate enjoyment and } \\
\text { enthusiasm. }\end{array}$} & $\mathrm{F}$ & 210 & 129 & 27 & 7 & 2 & \multirow[b]{2}{*}{$4 \cdot 43$} & \multirow{2}{*}{0.753} & \multirow{2}{*}{4} \\
\hline & & $\%$ & 56 & $34 \cdot 4$ & 7.2 & 1.9 & 0.5 & & & \\
\hline \multirow{2}{*}{14} & \multirow{2}{*}{ The programs of sports for all fit social values. } & $\mathrm{F}$ & 139 & 144 & 83 & 7 & 2 & \multirow{2}{*}{4.10} & \multirow{2}{*}{0.841} & \multirow{2}{*}{5} \\
\hline & & $\%$ & 37.1 & 38.4 & 22.1 & 1.9 & 0.5 & & & \\
\hline
\end{tabular}




\begin{tabular}{|c|c|c|c|c|c|c|c|c|c|c|}
\hline \multirow[b]{2}{*}{ No. } & \multirow[b]{2}{*}{ Item } & \multirow{2}{*}{\begin{tabular}{|l|} 
Frequency \\
Percentage
\end{tabular}} & \multicolumn{5}{|c|}{ Agreement } & \multirow{2}{*}{ 总 } & \multirow{2}{*}{ 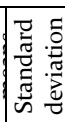 } & \multirow{2}{*}{ 䒕 } \\
\hline & & & $\begin{array}{l}\text { Strongly } \\
\text { agree }\end{array}$ & Agree & Undecided & Disagree & $\begin{array}{l}\text { Strongly } \\
\text { disagree }\end{array}$ & & & \\
\hline \multirow{2}{*}{18} & \multirow{2}{*}{ Off-campus sport exercises are better. } & $\mathrm{F}$ & 157 & 94 & 91 & 30 & 3 & \multirow[b]{2}{*}{3.99} & \multirow{2}{*}{1.028} & \multirow{2}{*}{6} \\
\hline & & $\%$ & 41.8 & 25.1 & 24.3 & 8 & 0.8 & & & \\
\hline \multirow[b]{2}{*}{10} & \multirow{2}{*}{$\begin{array}{l}\text { The interest of the society and mass media in } \\
\text { educating individuals about sports make me feel } \\
\text { satisfied. }\end{array}$} & $\mathrm{F}$ & 127 & 142 & 61 & 39 & 6 & \multirow[b]{2}{*}{3.92} & \multirow[b]{2}{*}{1.028} & \multirow[b]{2}{*}{7} \\
\hline & & $\%$ & 33.8 & $37 \cdot 9$ & 16.3 & 10.4 & 1.6 & & & \\
\hline \multirow{2}{*}{13} & \multirow{2}{*}{$\begin{array}{l}\text { On-campus sports activities improve the daily } \\
\text { routine of lectures. }\end{array}$} & $\mathrm{F}$ & 135 & 113 & 94 & 23 & 10 & \multirow[b]{2}{*}{3.91} & \multirow[b]{2}{*}{1.044} & \multirow{2}{*}{8} \\
\hline & & $\%$ & 36 & 30.1 & 25.1 & 6.1 & 2.7 & & & \\
\hline \multirow{2}{*}{17} & \multirow{2}{*}{$\begin{array}{l}\text { On-campus sport exercises increase fatigue and } \\
\text { tiredness and affect other lectures. }\end{array}$} & $\mathrm{F}$ & 84 & 74 & 108 & 75 & 34 & \multirow{2}{*}{3.26} & \multirow{2}{*}{1.261} & \\
\hline & & $\%$ & 22.4 & 19.7 & 28.8 & 20 & 9.1 & & & 9 \\
\hline \multicolumn{8}{|c|}{ Total } & 4.14 & \multicolumn{2}{|c|}{0.483} \\
\hline
\end{tabular}

Table (7) shows that the participants agreed on this domain. They strongly agreed on items $(16,15,11$, and 12), agreed on items (14, 18, 10, and 13), and undecided on item (17). Item (16) was ranked first because the students feel mentally and physically active after exercising, so they feel relaxed and happy. In terms of the agreement, item (13) was ranked last because the students feel that sports reduce the burden of the daily routine of lectures, so their emotional aspect was promoted. However, the participants were undecided on item (17). That is, they were not sure whether sport increases fatigue and affects the lectures negatively or not. Thus, the emotional aspect of this item was promoted.

To identify the behavioral aspect of the student attitude towards participation in sports for all, the frequency, percentage, arithmetic mean, standard deviation, and rank of the responses were calculated.

Table (8): Responses of the participants to the behavioral aspect of the attitudes of university students to participate in sports for all

\begin{tabular}{|c|c|c|c|c|c|c|c|c|c|c|}
\hline \multirow[b]{2}{*}{ No } & \multirow[b]{2}{*}{ Item } & \multirow{2}{*}{\begin{tabular}{|l|} 
Frequency \\
Percentage \\
\end{tabular}} & \multicolumn{5}{|c|}{ Agreement } & \multirow{2}{*}{ 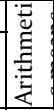 } & \multirow{2}{*}{ 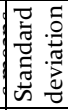 } & \multirow{2}{*}{$\underset{\widetilde{Z}}{\mathscr{Z}}$} \\
\hline & & & $\begin{array}{l}\text { Strongly } \\
\text { agree }\end{array}$ & Agree & Undecided & Disagree & $\begin{array}{l}\text { Strongly } \\
\text { disagree }\end{array}$ & & & \\
\hline \multirow{2}{*}{20} & \multirow{2}{*}{ Sport keeps my body fit. } & $\mathrm{F}$ & 279 & 92 & 3 & 1 & - & \multirow[b]{2}{*}{$4 \cdot 73$} & \multirow[b]{2}{*}{0.479} & \multirow{2}{*}{1} \\
\hline & & $\%$ & 74.4 & 24.5 & 0.8 & 0.3 & - & & & \\
\hline \multirow{2}{*}{19} & \multirow{2}{*}{$\begin{array}{l}\text { Sport exercises are important for health and } \\
\text { disease resistance. }\end{array}$} & $\mathrm{F}$ & 273 & 95 & 7 & - & - & \multirow[b]{2}{*}{$4 \cdot 71$} & \multirow{2}{*}{0.494} & \multirow{2}{*}{2} \\
\hline & & $\%$ & 72.8 & 25.3 & 1.9 & - & - & & & \\
\hline \multirow{2}{*}{27} & \multirow{2}{*}{$\begin{array}{l}\text { As a lifestyle, sport is essential and important in } \\
\text { modern life. }\end{array}$} & $\mathrm{F}$ & 228 & 124 & 21 & 2 & - & \multirow[b]{2}{*}{$4 \cdot 54$} & \multirow{2}{*}{0.627} & \multirow{2}{*}{3} \\
\hline & & $\%$ & 60.8 & 33.1 & 5.6 & 0.5 & - & & & \\
\hline \multirow{2}{*}{25} & \multirow{2}{*}{ Sport exercises reduce tension. } & $\mathrm{F}$ & 229 & 119 & 23 & 4 & - & \multirow{2}{*}{4.53} & \multirow{2}{*}{0.661} & \multirow{2}{*}{4} \\
\hline & & $\%$ & 61.1 & 31.7 & 6.1 & 1.1 & - & & & \\
\hline \multirow{2}{*}{23} & \multirow{2}{*}{$\begin{array}{l}\text { On-campus walking and movement instead of } \\
\text { using assistive devices (golf cart) increase my } \\
\text { activity. }\end{array}$} & $\mathrm{F}$ & 209 & 118 & 20 & 19 & 9 & \multirow[b]{2}{*}{$4 \cdot 33$} & \multirow[b]{2}{*}{0.960} & \multirow[b]{2}{*}{5} \\
\hline & & $\%$ & $55 \cdot 7$ & 31.5 & $5 \cdot 3$ & 5.1 & 2.4 & & & \\
\hline \multirow{2}{*}{22} & Following figures interested in sports via social & $\mathrm{F}$ & 173 & 133 & 26 & 36 & 7 & & & \\
\hline & media motivate me to practice sports. & $\%$ & 46.1 & 35.5 & 6.9 & 9.6 & 1.9 & 4.14 & 1.032 & 0 \\
\hline 24 & Sport exercises encourage participation in student & $\mathrm{F}$ & 125 & 102 & 106 & 37 & 5 & 381 & 1.048 & \\
\hline 24 & activities at the university. & $\%$ & $33 \cdot 3$ & 27.2 & 28.3 & 9.9 & 1.3 & 3.01 & 1.040 & 7 \\
\hline & Sport helps build relationships and friendships & $\mathrm{F}$ & 118 & 101 & 105 & 46 & 5 & & & \\
\hline 21 & that fit my interests and attitudes. & $\%$ & 31.5 & 26.9 & 28 & 12.3 & 1.3 & $3 \cdot 75$ & 1.070 & 8 \\
\hline 26 & Sport enhances academic achievement. & $\mathrm{F}$ & 87 & 75 & 130 & 61 & 22 & & & \\
\hline 20 & sport entidices deduentic dcrileventent. & $\%$ & 23.2 & 20 & 34.6 & 16.3 & $5 \cdot 9$ & 3.30 & 1.175 & 9 \\
\hline Tot & & & & & & & & 4.21 & 0.52 & \\
\hline
\end{tabular}

Table (8) illustrates that the participants strongly agreed on this domain. They strongly agreed on items (20, 19, 27, 25, and 23), agreed on items (24, 22, and 21), and undecided on item (26). Item (20) was ranked first, showing that the students understand that sport reduces fat and keeps the body fit. Thus, the behavioral domain was promoted. This finding matched Alhabdan (2017) that sport exercises keep 
good health and improve fitness. It also agrees with Zayed et al. (2004) that revealed positive attitudes among the students of Sultan Qaboos University towards the sports activity for health and fitness and the sports activity as an aesthetic experience. In terms of the agreement, item (21) was ranked last, indicating that the students' sport helps make new friends. They undecided on item (26), showing that students may think that sport exercises take time. Therefore, the behavioral aspect reduces concerning sports enhance academic achievement.

To answer the second question, the arithmetic mean, standard deviation, percentage, and rank of the participants' responses to the obstacles that hinder the participation of university students in sports for all in the Saudi society were calculated.

Table (9): Responses of the participants to the obstacles that hinder the participation of university student in sports for all in the Saudi society

\begin{tabular}{|c|c|c|c|c|c|c|c|c|c|c|}
\hline \multirow[b]{2}{*}{ No. } & \multirow[b]{2}{*}{ Item } & \multirow{2}{*}{\begin{tabular}{|l|} 
Frequency \\
Percentage
\end{tabular}} & \multicolumn{5}{|c|}{ Agreement } & \multirow{2}{*}{ 总 } & \multirow{2}{*}{ 语 } & \multirow{2}{*}{ 氞 } \\
\hline & & & $\begin{array}{c}\text { Strongly } \\
\text { agree }\end{array}$ & Agree & Undecided & Disagree & $\begin{array}{l}\text { Strongly } \\
\text { disagree }\end{array}$ & & & \\
\hline \multirow{2}{*}{11} & \multirow{2}{*}{$\begin{array}{l}\text { Temperature and weather fluctuations, such as } \\
\text { dust hinder sport exercises outside the house. }\end{array}$} & $\mathrm{F}$ & 133 & 143 & 29 & 45 & 25 & \multirow{2}{*}{3.84} & \multirow{2}{*}{1.220} & \multirow{2}{*}{1} \\
\hline & & $\%$ & $35 \cdot 5$ & 38.1 & $7 \cdot 7$ & 12 & 6.7 & & & \\
\hline \multirow{2}{*}{9} & \multirow{2}{*}{ Spare time runs short. } & $\mathrm{F}$ & 146 & 118 & 39 & 50 & 22 & \multirow{2}{*}{3.84} & \multirow{2}{*}{1.239} & \multirow{2}{*}{2} \\
\hline & & $\%$ & 38.9 & 31.5 & 10.4 & 13.3 & 5.9 & & & \\
\hline \multirow{2}{*}{12} & \multirow{2}{*}{$\begin{array}{l}\text { Wearing a hijab with sportswear hinder } \\
\text { participation in sports for all outside the house. }\end{array}$} & $\mathrm{F}$ & 105 & 96 & 49 & 64 & 61 & \multirow[b]{2}{*}{3.32} & \multirow[b]{2}{*}{1.449} & \multirow[b]{2}{*}{3} \\
\hline & & $\%$ & 28 & 25.6 & 13.1 & 17.1 & 16.2 & & & \\
\hline \multirow{2}{*}{3} & \multirow{2}{*}{$\begin{array}{l}\text { I am not fully aware of the activities of sports for } \\
\text { all. }\end{array}$} & $\mathrm{F}$ & 48 & 149 & 71 & 79 & 28 & \multirow{2}{*}{3.29} & \multirow[b]{2}{*}{1.156} & \multirow[b]{2}{*}{4} \\
\hline & & $\%$ & 12.8 & 39.7 & 18.9 & 21.1 & 7.5 & & & \\
\hline \multirow{2}{*}{10} & \multirow{2}{*}{$\begin{array}{l}\text { A means of transportation from and to the places } \\
\text { of sport exercises is not available. }\end{array}$} & $\mathrm{F}$ & 88 & 108 & 46 & 88 & 45 & & & \\
\hline & & $\%$ & 23.5 & 28.7 & 12.3 & 23.5 & 12 & 3.20 & 1.300 & 5 \\
\hline & I cannot afford the fees for the sports club's & $\mathrm{F}$ & 59 & 121 & 58 & 97 & 40 & & & \\
\hline 2 & subscriptions. & $\%$ & $15 \cdot 7$ & 32.2 & 15.5 & 25.9 & 10.7 & 3.17 & 1.271 & 6 \\
\hline & Harassment hinders exercise outside the house. & $\mathrm{F}$ & 59 & 77 & 95 & 79 & 65 & & & \\
\hline 13 & Harassment ninaers exercise outside the nouse. & $\%$ & 15.7 & 20.6 & $25 \cdot 3$ & 21.1 & $17 \cdot 3$ & 2.96 & 1.320 & 7 \\
\hline & The lack of sports facilities and activities on- & $\mathrm{F}$ & 39 & 79 & 94 & 115 & 48 & & & \\
\hline 6 & campus hinders participation in sports for all. & $\%$ & 10.4 & 21.1 & 25 & 30.7 & 12.8 & 2.86 & 1.195 & 8 \\
\hline & The lack of a track in the neighborhood motivates & $\mathrm{F}$ & 51 & 84 & 37 & 120 & 83 & & & \\
\hline 8 & me not to exercise. & $\%$ & 13.6 & 22.4 & 9.9 & 32 & 22.1 & 2.73 & 1.381 & 9 \\
\hline & Customs and traditions hinder the practice of & $\mathrm{F}$ & 42 & 67 & 47 & 115 & 104 & & & \\
\hline 5 & sports for all. & $\%$ & 11.2 & 17.9 & 12.5 & 30.7 & 27.7 & 2.54 & 1.355 & 10 \\
\hline & & $\mathrm{F}$ & 21 & 49 & 29 & 154 & 122 & & & \\
\hline 1 & My family does not encourage sport. & $\%$ & 5.6 & 13.1 & 7.7 & 41.1 & 32.5 & 2.18 & 1.183 & 11 \\
\hline & My health condition does not allow sport & $\mathrm{F}$ & 15 & 30 & 22 & 123 & 185 & & & \\
\hline 7 & exercises. & $\%$ & 4 & 8 & 5.9 & 32.8 & $49 \cdot 3$ & 1.85 & 1.101 & 12 \\
\hline & & $\mathrm{F}$ & 14 & 19 & 35 & 126 & 181 & & & \\
\hline 4 & Sport is not useful. & $\%$ & 3.7 & 5.1 & $9 \cdot 3$ & 33.6 & 48.3 & 1.82 & 1.042 & 13 \\
\hline Tot & & & & & & & & 2.90 & & 64 \\
\hline
\end{tabular}

Table (9) illustrates the most significant obstacles are temperature and weather fluctuations, such as dust. Moreover, the lack of spare time hinders the practice of sports activities. This finding matches the results of Alhabbay (2018) and Barsom (2003) that lack of time hinders exercise. The participants do not believe that customs and traditions hinder sports for all. However, Alkabey (2013) revealed that the Saudi customs and traditions do not allow women's sports. Furthermore, the participants perceived the importance and benefits of sport.

To answer the third question, the arithmetic mean, standard deviation, percentage, and rank of the participants' responses to the suggestions of activating the participation of university students in sports for all in the Saudi society were calculated. 
Table (10): Responses of the suggestions of activating the participation of university student in sports for all in the Saudi society

\begin{tabular}{|c|c|c|c|c|c|c|c|c|c|c|}
\hline \multirow[b]{2}{*}{ No } & \multirow[b]{2}{*}{ Item } & \multirow{2}{*}{\begin{tabular}{|l} 
Frequency \\
Percentage
\end{tabular}} & \multicolumn{5}{|c|}{ Agreement } & \multirow{2}{*}{ 离 } & \multirow{2}{*}{ 焉 } & \multirow{2}{*}{ 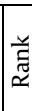 } \\
\hline & & & $\begin{array}{l}\text { Strongly } \\
\text { agree }\end{array}$ & Agree & Undecided & Disagree & $\begin{array}{l}\text { Strongly } \\
\text { disagree }\end{array}$ & & & \\
\hline \multirow{2}{*}{9} & \multirow{2}{*}{ Discounts for university students at sports clubs. } & $\mathrm{F}$ & 285 & 77 & 11 & 2 & - & \multirow{2}{*}{$4 \cdot 72$} & \multirow{2}{*}{0.541} & \multirow{2}{*}{1} \\
\hline & & $\%$ & 76.1 & 20.5 & 2.9 & 0.5 & - & & & \\
\hline \multirow{2}{*}{8} & \multirow{2}{*}{$\begin{array}{l}\text { Reducing the fees of subscriptions at women's } \\
\text { clubs. }\end{array}$} & $\mathrm{F}$ & 277 & 77 & 21 & - & - & \multirow{2}{*}{4.68} & \multirow{2}{*}{0.574} & \multirow{2}{*}{2} \\
\hline & & $\%$ & 73.9 & 20.5 & 5.6 & - & - & & & \\
\hline \multirow{2}{*}{6} & \multirow{2}{*}{$\begin{array}{l}\text { Increasing the number of women's clubs in the } \\
\text { neighborhood. }\end{array}$} & $\mathrm{F}$ & 251 & 102 & 16 & 5 & 1 & \multirow{2}{*}{$4 \cdot 59$} & \multirow{2}{*}{0.663} & \multirow{2}{*}{3} \\
\hline & & $\%$ & 66.9 & 27.2 & $4 \cdot 3$ & 1.3 & 0.3 & & & \\
\hline \multirow{2}{*}{11} & \multirow{2}{*}{$\begin{array}{l}\text { Launching an electronic application about the } \\
\text { places, events, and timing of the programs of } \\
\text { sports for all. }\end{array}$} & $\mathrm{F}$ & 254 & 94 & 18 & 7 & 2 & \multirow[b]{2}{*}{4.58} & \multirow[b]{2}{*}{0.719} & \multirow[b]{2}{*}{4} \\
\hline & & $\%$ & $67 \cdot 7$ & 25.1 & 4.8 & 1.9 & 0.5 & & & \\
\hline \multirow[b]{2}{*}{4} & \multirow{2}{*}{$\begin{array}{l}\text { Preparing and equipping areas of the } \\
\text { neighborhood parks to practice some sports } \\
\text { besides walking. }\end{array}$} & $\mathrm{F}$ & 234 & 122 & 11 & 6 & 2 & \multirow[b]{2}{*}{4.55} & \multirow[b]{2}{*}{0.684} & \\
\hline & & $\%$ & 62.5 & 32.5 & 2.9 & 1.6 & 0.5 & & & 5 \\
\hline 2 & Holding various and free sports events in the & $\mathrm{F}$ & 217 & 139 & 12 & 6 & 1 & & & \\
\hline 2 & public facilities. & $\%$ & 57.8 & 37.1 & 3.2 & 1.6 & 0.3 & $4 \cdot 51$ & 0.666 & 6 \\
\hline 1 & Interest in raising awareness about sport exercises & $\mathrm{F}$ & 202 & 150 & 17 & 4 & 2 & & & \\
\hline 1 & as a lifestyle via mass media and social media. & $\%$ & 53.9 & 40 & 4.5 & 1.1 & 0.5 & 4.46 & 0.684 & 7 \\
\hline & & $\mathrm{F}$ & 227 & 108 & 24 & 14 & 2 & & & \\
\hline 7 & Holding free sports activities on-campus regularly. & $\%$ & 60.6 & 28.8 & 6.4 & 3.7 & 0.5 & 4.45 & 0.816 & 8 \\
\hline 10 & Paying much interest in building sports teams on- & $\mathrm{F}$ & 211 & 113 & 39 & 10 & 2 & & 0810 & 0 \\
\hline 10 & campus (walking, bicycling, etc.) & $\%$ & 56.3 & 30.1 & 10.4 & 2.7 & 0.5 & 4.39 & 0.00 & 9 \\
\hline & Utilizing commercial stores and dedicating an area & $\mathrm{F}$ & 206 & 119 & 25 & 20 & 5 & & & \\
\hline 3 & $\begin{array}{l}\text { for walking and sports because they are air- } \\
\text { conditioned. }\end{array}$ & $\%$ & $54 \cdot 9$ & 31.8 & 6.7 & $5 \cdot 3$ & 1.3 & $4 \cdot 34$ & 0.916 & 10 \\
\hline & Installment payments help buy sports devices at & $\mathrm{F}$ & 171 & 135 & 53 & 14 & 2 & & 864 & \\
\hline 5 & home. & $\%$ & $45 \cdot 7$ & 36 & 14.1 & 3.7 & 0.5 & 4.22 & 0.004 & \\
\hline Tot & & & & & & & & 4.50 & & \\
\hline
\end{tabular}

Table (10) illustrates that the participants strongly agreed on this domain. Item (9) was ranked first, showing that offering discounts for university students at clubs reduces cost and motivates the practice of sports. However, some students may not know that well-known clubs offer discounts. Item (5) was ranked last, indicating that installment payments help buy sports devices at home to practice sports.

\section{Conclusion}

The development of situations and beliefs has changed the causes and conditions of women's practice of sports worldwide. Sports for all are a must and a type of treatment and rehabilitation, especially for keeping health and fitness and improving the psychological, emotional, and social conditions. Moreover, joining sports activities should be optional. The study examined the attitude of female university students in Saudi Arabia towards participation in sports for all. It recommends raising awareness about sports for all by the collaboration of the Saudi Sports for All Federation, General Entertainment Authority, Ministry of Health, and Province Secretariats. The various social institutions should raise health awareness about the practice of sports as a lifestyle by posting an attractive and authentic value content to mass media and social media. Moreover, the number of women's clubs should be increased and supported in the neighborhoods and symposia should be held at universities to disseminate sports for all among students.

\section{Acknowledgments}

The researcher thanks the Center for Promising Research in Social Research and Women's Studies at Princess Nourah bint Abdulrahman University for funding this research project.

\section{References}

Abdelsalam, M. and Amer, R. (2016). Women's attitudes towards sports for all in Port Said according to some variables. Scientific Journal of Physical and Sports Education, 76. 
Alamodey, A. (2016, December 26). Development of women's sports in Saudi Arabia. Hiamag. Retrieved from https://bit.ly/2XOPmQy.

Alatrash, M. (2016). Attitudes towards sports activity after studying the Physical Fitness Course at An-Najah National University. Educational Sciences, 43(3), 1415-1422.

Alhabbay, M. (2018). Social determinants affecting the formation of health awareness among Saudi youth (M.A. thesis). King Saud University, Saudi Arabia.

Alhabdan, A. (2017). A social study on the impact of sports practice on the girls in Riyadh. Journal of Social Work, 2(57). Alhamed, D. (2015, June 16). Benefits of sports in the morning. Mawdoo. Retrieved from https://bit.ly/3gGTTgw.

Alkabey, M. (2013). Sociocultural determinants affecting the women's practice of sports in Saudi society (M.A. thesis). King Saud University, Riyadh.

Aljafra, I. (2013). The attitude of secondary school students to practicing the sports activity in Physical Education Class in Ma'an Governorate. Journal of Education and Childhood, 15(1), 17-6o.

Aljebaly, H. (2003). Social psychology: Theory and practice ( $1^{\text {st }}$ ed.). Cairo: Anglo-Egyptian Bookshop.

Aljifri, A. (2013). Attitudes of King Abdulaziz University students in Saudi Arabia towards physical activity. An-Najah University Journal for Research - Humanities, 28(8), 1900-1922.

Alsaleh, H. (2016, November 18). A princess changing women's sports in Saudi Arabia. Al Arabiya. Retrieved from http://ara.tv/pz8qk.

Alsayed, M. and Abdelsalam, M. (2014). The attitudes of the students of the Faculty of Physical Education for Boys in Helwan towards sports for all. The Scientific Journal of Physical Education and Sport Sciences, 1(71),

Alshahrey, S. (2007). The relationship between physical activity, fitness, and achievement among the students of the intermediate and secondary stages (M.A. thesis). King Saud University, Riyadh.

Alwalaney, B. (2015). Sports for recreation and quality of life. Riyadh: Naif Arab University for Security Sciences.

Alzahra, B. (2006). The attitudes of women towards some social issues in the light of some demographic variables (M.A. thesis). Université Kasdi Merbah Ouargla, Algeria.

Barsom, S. (2003). Reasons for the reluctance of students at Helwan University hostels to participate in the sports activity (M.A. thesis). Faculty of Physical Education for Girls, Cairo.

Coakley, J. (2014). Sports in society: Issues and controversies ( $11^{\text {th }}$ ed.). Irwin: McGraw-Hill

General Authority for Statistics (2010). Importance of sports for the woman. Retrieved from www.saudistat.net25.

Grissom, J. (2005). Physical fitness and academic achievement. Journal of Exercise Physiology Online, 8(1), 11-25.

Hall, E. (2005). Living well in 2005! The benefits of leisure for people with disabilities. National Center on Accessibility. Access Today, 18(Spring), 1-14.

Kenza, J. (2014). Attitudes of university students towards graffiti (M.A. thesis). Mohamed Khider University of Biskra, Algeria.

Mahmoud, I. (2012). Studying the concepts and obstacles of sports practice among the female students of Qatar University. Sweden: International Academy of Sports Technology.

Marques, A., Martins, J., Santos, F., Sarmento, H., \& Carreiro da Costa, F. (2014). Correlates of school sport participation: A cross-sectional study in urban Portuguese students. Science \& Sports, 29(4), 31-38.

Ministry of Health (2016). Health information survey. Retrieved from: https://www.moh.gov.sa/ministry/statistics /pages/healthinformatics.aspx.

Mirsafian, H., Dóczi, T. \& Mohamadinejad, A. (2014). Attitude of Iranian female university students to sport and exercise. Iranian Studies, 47(6), 951-966.

Mousavi, S. (2012). Evaluation and comparison of individual and group sports in the social adjustment of students. International Journal of Academic Research in Business and Social Sciences, 2(1), 274-277.

Perks, T. (2019). Trajectories of sport participation among children and adolescents across different socio-economic categories: Multilevel findings from the national longitudinal survey of children and youth. Sociology of Sport Journal, 1-5.

Saudi Vision 2030 (2016, April 15). Saudi Vision 2030. Retrieved from https://visionzozo.gov.sa/en.

World Health Organization (2010). Physical activity. Retrieved from: https://www.who.int/ar/news-room/factsheets/detail/physical-activity.

Zayed, K., Al-Jebali, M. \& Al-Shoaili, A. (2004). Attitudes of the students of Sultan Qaboos University towards sports activity and relationship to some variables. Journal of Psychological and Educational Studies, 8, 47-76.

Zeyab, A. (2004). Attitudes of Kuwait University students to sports for all. Assiut Journal of Physical Education, 3(19), $113-129$.

Zober, A. (2014). Attitudes of the secondary stage students towards physical education and relationship to achievement motivation (M.A. thesis). University of M'sila, Algeria. 